\title{
Natural products from Zanthoxylum heitzii with potent activity against the malaria parasite
}

\author{
Christopher Dean Goodman ${ }^{1 \dagger}$, Ingvild Austarheim ${ }^{2 \dagger}$, Vanessa Mollard ${ }^{1}$, Bertin Mikolo ${ }^{3}$, Karl Egil Malterud ${ }^{2}$, \\ Geoffrey I. McFadden ${ }^{1 \neq}$ and Helle Wangensteen ${ }^{2^{*}}$
}

\begin{abstract}
Background: Zanthoxylum heitzii (Rutaceae) (olon) is used in traditional medicine in Central and West Africa to treat malaria. To identify novel compounds with anti-parasitic activity and validate medicinal usage, extracts and compounds isolated from this tree were tested against the erythrocytic stages of the human malaria parasite Plasmodium falciparum and for inhibition of transmission in rodent malaria parasite Plasmodium berghei.

Results: Hexane bark extract showed activity against P. falciparum $\left(I C_{50} 0.050 \mu \mathrm{g} / \mathrm{ml}\right)$, while leaf and seed extracts were inactive. Fractionation of the hexane bark extract led to the identification of three active constituents; dihydronitidine, pellitorine and heitziquinone. Dihydronitidine was the most active compound with an $\mathrm{I}_{50}$ value of $0.0089 \mu \mathrm{g} /$ $\mathrm{ml}(25 \mathrm{nM})$. This compound was slow acting, requiring $50 \%$ longer exposure time than standard anti-malarials to reach full efficacy. Heitziquinone and pellitorine were less potent, with $I C_{50}$ values of $3.55 \mu \mathrm{g} / \mathrm{ml}$ and $1.96 \mu \mathrm{g} / \mathrm{ml}$, but were fast-acting. Plasmodium berghei ookinete conversion was also inhibited by the hexane extract $\left(I C_{50} 1.75 \mu \mathrm{g} / \mathrm{ml}\right)$, dihydronitidine $(0.59 \mu \mathrm{g} / \mathrm{ml})$ and heitziquinone $(6.2 \mu \mathrm{g} / \mathrm{ml})$. Water extracts of $Z$. heitzii bark contain only low levels of dihydronitidine and show modest anti-parasitic activity.
\end{abstract}

Conclusions: Three compounds with anti-parasitic activity were identified in Z. heitzii bark extract. The alkaloid dihydronitidine is the most effective of these, accounting for the bulk of activity in both erythrocytic and transmissionblocking assays. These compounds may present good leads for development of novel anti-malarials and add to the understanding of the chemical basis of the anti-parasitic activity in these classes of natural product.

Keywords: Zanthoxy/um heitzii, Rutaceae, Dihydronitidine, Anti-malarial, Benzophenanthridine alkaloid, Ookinete, Transmission blocking, Malaria, Ethnobotany

\section{Background}

In many African countries with high rates of malaria transmission, there is a common tradition of using native plants to treat malaria. The most seriously affected countries are associated with a dysfunctional health system and poverty [1], and accessibility to anti-malarial

\footnotetext{
${ }^{*}$ Correspondence: helle.wangensteen@farmasi.uio.no

${ }^{\dagger}$ Christopher Dean Goodman and Ingvild Austarheim contributed equally to this work

${ }^{\ddagger}$ Geoffrey I. McFadden and Helle Wangensteen contributed equally to this work

2 Department of Pharmaceutical Chemistry, School of Pharmacy, University of Oslo, P. O. Box 1068, Blindern, 0316 Oslo, Norway Full list of author information is available at the end of the article
}

treatment is often inadequate or non-existent. Where available, free artemisinin combination therapy (ACT) is limited to pregnant women and children under 5 years of age [1], making expenditure on malaria treatment a huge burden for middle-income households and essentially unaffordable for most of the population who live on less than $\$ 2$ a day [2]. Substandard and counterfeit anti-malarials are also major concerns and contribute to drug resistance $[3,4]$. Use of herbal anti-malarials in sub-Saharan Africa is widespread, although the reported prevalence varies considerably. A meta-analysis from 2004 indicates an overall prevalence of $24 \%$, but regional use varied from 0 to $75 \%$ [5]. Use of traditional medicine 
is most prevalent in rural and poor areas where it plays a very important role for disease control [6]. Traditional medicines have provided the basis for highly effective anti-malarials: the quinine and artemisinin derivatives. With resistance to artemisinin derivatives currently on the rise [7], identifying novel anti-malarials and understanding the efficacy of traditional remedies is of increasing importance.

Members of the genus Zanthoxylum are widely used as traditional medicines for the treatment and prevention of malaria [8-10]. Zanthoxylum spp. are well known for producing an array of complex secondary metabolites, especially benzophenanthridine alkaloids, some of which have previously been shown to have anti-malarial activity [11-14]. The in vitro efficacy of these compounds lends support for their use in traditional medicine. The tree Zanthoxylum heitzii (syn. Fagara heitzii), grows over a range that encompasses many areas of high malaria transmission in Central-West Africa [10]. In this area, the bark is traditionally used to treat malaria [10]. Zanthoxylum heitzii bark extracts and major components of the extracts have previously been shown to have insecticidal activity [16-18] but it is unknown if $Z$. heitzii contains any compounds with significant antiparasitic activity.

This paper investigates the activity of extracts and chemical components isolated from $Z$. heitzii against the malaria parasites, Plasmodium falciparum and Plasmodium berghei to investigate the scientific rationale behind the traditional use against malaria. Fractionation and in vitro testing against $P$. falciparum identified three compounds with significant anti-parasitic activity, with one, dihydronitidine, being active at low nanomolar concentrations.

\section{Methods}

\section{Plant material}

Stem bark, seeds and leaves of Zanthoxylum heitzii (Rutaceae) were harvested in Douakani, Republic of Congo during November 2011. Voucher samples are kept in the Section of Pharmacognosy, School of Pharmacy, University of Oslo, registry number ZH-B-111202 (bark), ZH-L-111201 (leaf) and ZH-S-111203 (seed). This work was carried out in accordance with the Nagoya convention.

\section{Extraction and isolation of natural compounds}

The plant material was extracted and natural products isolated according to Moussavi et al. [18] and Wangensteen et al. [19]. Briefly, the stem bark, seeds and leaves were air dried and made into a powder $(<1 \mathrm{~mm})$. The powdered plant materials were first extracted with hexane in a Soxhlet extractor until the effluent was colorless, and then subsequently extracted with ethyl acetate and ethanol in an accelerated solvent extractor, ASE350 (Dionex) [17]. The pure compounds were obtained from the bark hexane extract as previously described $[18,19]$ by Si-gel normal phase and reverse phase C18 chromatography. The powdered bark $(<1 \mathrm{~mm}), 10 \mathrm{~g}$, was mixed with $100 \mathrm{~g}$ water and refluxed for $20 \mathrm{~min}$ to mimic a common way of preparing herbal drugs, making a decoction. The decoction was filtered through glass wool when hot and lyophilized in aliquots of $1 \mathrm{ml}$, corresponding to $\sim 10 \mathrm{mg}$ dry weight.

\section{Quantification of dihydronitidine}

The dihydronitidine content in hexane, ethyl acetate (EtOAc) and ethanol (EtOH) extracts from bark, leaf and seeds, as well as boiling water extract of the bark, was quantified by C18-HPLC. The dried extracts were dissolved by sonication (10 $\mathrm{min}$ ) in acetonitrile (final concentration $1-10 \mathrm{mg} / \mathrm{ml}$ ). The solutions were filtered (PTFT membrane, $0.22 \mu \mathrm{m}$ ) and the filtrate, $40 \mu \mathrm{l}$, was applied on a Chromolith Performance RP18e $100 \times 4.6 \mathrm{~mm}$ HPLC column (Merck) attached to LaChrom Elite HPLC system (VWR-Hitachi) equipped with an L-2455 diode array detector. Elution was performed using a gradient of mobile phase A (20 mM ammonium acetate) and mobile phase $\mathrm{B}$ (acetonitrile) with the following time schedule: $20 \% \mathrm{~B}, 0-1 \mathrm{~min}$; $20-90 \% \mathrm{~B}, 1-15 \mathrm{~min} ; 90 \% \mathrm{~B}, 15-16 \mathrm{~min}$. The flow rate was $3.0 \mathrm{ml} / \mathrm{min}$. The absorbance was recorded at 278 and $312 \mathrm{~nm}$, and separation took place at $25^{\circ} \mathrm{C}$.

\section{Purity of dihydronitidine}

The purity of dihydronitidine was estimated to be better than $97 \%$ from ${ }^{1} \mathrm{H}$ NMR spectroscopy (Additional file 1). Signals from nitidine were not detectable, and it was therefore assumed that dihydronitidine used in the in vitro assays was nitidine free. Dihydronitidine isolated from the hexane bark extract [18] was used in all assays.

\section{Stability of dihydronitidine in in vitro culture media}

Dihydronitidine ( $5 \mu \mathrm{l}, 10 \mathrm{mg} / \mathrm{ml}$ in DMSO) was added to $0.5 \mathrm{ml}$ of RPMI 1640 complete medium supplemented with sodium bicarbonate $(0.18 \%)$ and FBS $(0.5 \%)$ (Gibco) and incubated in triplicates at $37{ }^{\circ} \mathrm{C}$ for $0,24,48$ and $72 \mathrm{~h}$ (final concentration of dihydronitidine $100 \mu \mathrm{g} / \mathrm{ml}$ ). The solution was taken to dryness in a SpeedVac vacuum concentrator (Thermo Scientific) and subsequently dissolved in $1 \mathrm{ml}$ acetonitrile and sonicated for $10 \mathrm{~min}$. The filtrate, $40 \mu \mathrm{l}$, was analysed by HPLC as described above (Quantification of dihydronitidine). Nitidine chloride (Sigma) was used as standard. 


\section{Anti-parasitic activity in Plasmodium falciparum}

The chloroquine susceptible strain 3D7 and the chloroquine resistant strain $\mathrm{Dd} 2$ parasites were cultured according to existing protocols [20]. In vitro assays are based on the method of Smilkstein et al. [21] as modified by Goodman et al. [22]. In assays longer than $72 \mathrm{~h}$, the medium was changed after $72 \mathrm{~h}$ of parasite growth. For tests of dihydronitidine stability, drug was diluted in culture media as per standard assay protocol but incubated at $37^{\circ} \mathrm{C}$ for $24 \mathrm{~h}$ prior to initiation of in vitro assay by addition of parasites and blood. Fluorescence was measured using an Enspire fluorescent plate reader (Perkin Elmer).

\section{Transmission blocking assay (ookinete conversion assay)}

To assay inhibition of the early mosquito stages of parasite development, $P$. berghei gametocytes expressing green fluorescence protein (GFP) under the control of the ookinete specific promoter CTRP were induced to undergo in vitro fertilization and subsequent development to ookinete stage in a standard 96-well plate assay, essentially as described [23]. Successful development to ookinete stage was assayed by GFP fluorescence measured using an Enspire fluorescent plate reader (Perkin Elmer).

\section{Statistical analysis}

Relative fluorescence was corrected for background and normalized to untreated controls to generate values in percent parasitaemia. Drug concentrations were converted to a $\log$ scale prior to analysis. Each in vitro assay was done in triplicate and $\mathrm{IC}_{50}$ values calculated using the four component model available in the Prism 6 statistical package (GraphPad). Mean and standard error values were calculated from three independent assays unless otherwise stated.

\section{Results and discussion}

\section{Activity against Plasmodium falciparum in vitro cultures}

Extracts from the bark, leaf and seeds were screened for activity against $P$. falciparum in $48 \mathrm{~h}$ in vitro drug assays. The greatest activity was seen in bark extracts, regardless of the solvent, with hexane extracting the most active substances (Fig. 1). Leaf and seed extracts showed little to no anti-parasitic activity, so further analysis focused on the hexane extract of the bark. The bark extract was fractionated and the fractions tested for activity against P. falciparum (Additional file 2). The major components of the active fractions were purified and identified (Fig. 2) and further tested for anti-parasitic activity. The purified compounds dihydronitidine, heitziquinone and pellitorine (Fig. 2) showed significant anti-parasitic activity
(Table 1), with dihydronitidine being the most active compound $\left(\mathrm{IC}_{50}\right.$ of $\left.0.0089 \pm 0.0008 \mu \mathrm{g} / \mathrm{ml}\right)$.

Standard in vitro assays measuring anti-parasitic effects after $48 \mathrm{~h}$ exposure to dihydronitidine showed $\mathrm{IC}_{50}$ values of $0.3 \mu \mathrm{g} / \mathrm{ml}$, which are similar to published $\mathrm{IC}_{50}$ values for dihydronitidine [13, 24], but with an unusually flat dose response (Fig. 3a) suggesting a slow acting drug effect. To investigate this, assays were extended with drug exposure time to 72 and $120 \mathrm{~h}$. With $72 \mathrm{~h}$ of exposure, the $\mathrm{IC}_{50}$ was significantly lower (Table 1) and the drug response curves showed a typical dose response (Fig. 3b). Further increasing the length of drug exposure did not impact the effective concentration (Fig. 3b), precluding the possibility of "delayed death" drug response common to compounds targeting the parasite apicoplast [22]. Subsequent assays with hexane extracts of bark over $72 \mathrm{~h}$ revealed a significant reduction in effective concentration (compare Fig. 1 and Table 1), reflecting the fact that dihydronitidine comprises a significant proportion of the anti-parasitic activity of the extract.

Two other compounds extracted from $Z$. heitzii showed activity against $P$. falciparum; pellitorine and the recently reported alkaloid heitziquinone [19] (Table 1). These compounds were less active, with $\mathrm{IC}_{50}$ values of $1.96 \pm 0.12$ and $3.55 \pm 0.62 \mu \mathrm{g} / \mathrm{ml}$ respectively, but were fast acting, having normal dose response curves with $48 \mathrm{~h}$ of drug exposure (Fig. 3a) and no change in effective concentration with extended drug exposure. The observed $\mathrm{IC}_{50}$ for pellitorine $(1.96 \mu \mathrm{g} / \mathrm{ml})$ is similar to previously reported values [25].

Two of the three active compounds are benzophenanthridine alkaloids, and previous studies show that the anti-malarial activity of this class of compounds is very sensitive to even small changes in chemical structure [26]. Heitziquinone has an opened C-ring and is, therefore, to the knowledge of the authors, the first open C-ring benzophenanthridine alkaloid that shows anti-plasmodial activity. This suggests that a closed C-ring is not essential for activity and that the structure-activity relationship in benzophenanthridine alkaloids is complex. A greater range of benzophenanthridine alkaloid compounds will need to be tested to elucidate these relationships.

\section{Stability of dihydronitidine}

The simplest explanation for the slow acting nature of dihydronitidine is the progressive breakdown of this compound under culture conditions to products that have greater anti-parasitic activity. Nitidine, a possible product of dihydronitidine oxidation, is thought to be the main active ingredient in several traditional anti-malarial remedies used in other parts of the world [13, 27]. The reported $\mathrm{IC}_{50}$ values for nitidine in standard assays $(48 \mathrm{~h})$ 


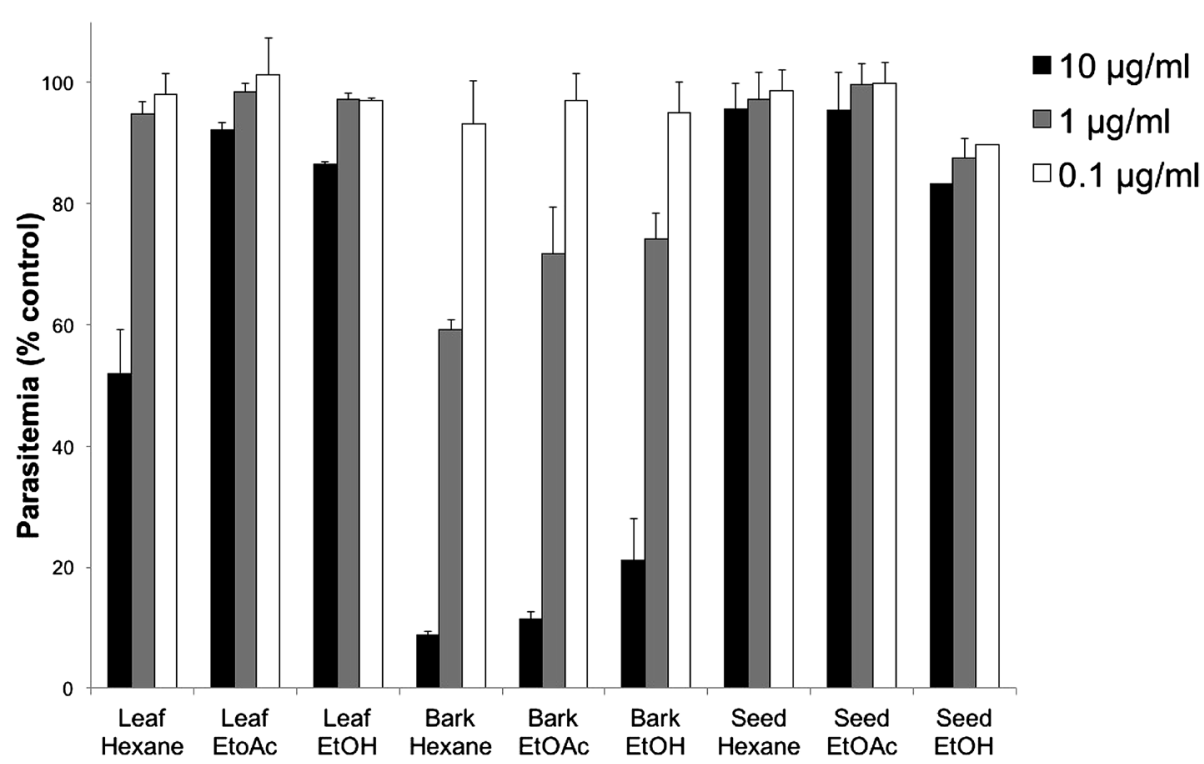

Fig. 1 In vitro activity against P. falciparum of crude extracts isolated from leaf, bark and seed of Z. heitzii. Mean of three technical replicates \pm standard deviation. EtOAc ethyl acetate; EtOH ethanol<smiles>COc1cc2c(cc1OC)-c1ccc3cc4c(cc3c1N(C)C2)OCO4</smiles>

Dihydronitidine<smiles>COc1cc(O)c(-c2ccc3cc4c(cc3c2N(C)C=O)OCO4)cc1OC</smiles>

Isoarnottianamide<smiles>COC1=CC(=O)C(c2ccc3cc4c(cc3c2N(C)O)OCO4)=CC1=O</smiles>

Heitziquinone<smiles>COc1cc2c(OC)nc3c4cc5c(cc4ccc3c2cc1OC)OCO5</smiles>

Rhoifoline B<smiles>CCCCC/C=C/C=C/C(=O)NCC(C)C</smiles>

Pellitorine<smiles>COc1cc2c[n+](C)c3c4cc5c(cc4ccc3c2cc1OC)OCO5</smiles>

Nitidine* $^{*}$

Fig. 2 Benzophenanthridine alkaloids and pellitorine isolated from Z. heitzii $[18,19]$. *Nitidine is included for structure comparison and was not present in the hexane extract

vary considerably $[13,26-28]$ but the lowest values fall in a similar range to those found for dihydronitidine in the long-exposure assays $(72 \mathrm{~h})$. It was reported previously that dihydronitidine may be slowly oxidized to nitidine under aerobic conditions [28]. To test its stability under culture conditions, dihydronitidine was incubated in parasite growth medium for $72 \mathrm{~h}$ at $37{ }^{\circ} \mathrm{C}$ and analysed at $24 \mathrm{~h}$ intervals to identify any breakdown products. Even prolonged incubation over $72 \mathrm{~h}$ did not significantly reduce the concentration of dihydronitidine in the sample (Fig. 4a) nor result in the production of detectable levels of nitidine. To further test whether dihydronitidine, and not its breakdown products, are responsible for the observed anti-parasitic activity, dihydronitidine was diluted in culture media in a 96 well plate according to the in vitro assay protocol and incubated at $37^{\circ} \mathrm{C}$ for $24 \mathrm{~h}$. Parasites were then added to initiate the in vitro assay and anti-parasitic activity was tested after $48 \mathrm{~h}$. Preincubation had little effect on the slow acting nature of dihydronitidine (Fig. 4b) suggesting that dihydronitidine, and not its breakdown products, is responsible for the observed anti-parasitic effects. 
The structural similarity between nitidine and dihydronitidine suggests that these compounds may share a mechanism of action. In this case, we would expect nitidine to show slow acting response similar to dihydronitidine. However, the observed activity of nitidine over $72 \mathrm{~h}$ (Table 1) was consistent with previously reported effective concentrations reported for shorter drug exposures $[13,27]$. This agrees with the chemical characteristics of the compounds. While nitidine was suggested to act by binding to DNA [24], it was later reported that nitidine forms a 1-1 complex with haem in vitro and also inhibits $\beta$-haematin formation with the same potency as chloroquine [27], so it has been postulated that nitidine activity is similar to chloroquine; interfering with haemozoin

Table 1 Inhibitory activity of hexane bark extract of $Z$. heitzii and pure compounds isolated from the extract against $P$. falciparum in $72 \mathrm{~h}$ assays

\begin{tabular}{lll}
\hline & $\begin{array}{l}\mathbf{I C}_{\mathbf{5 0}} \\
(\boldsymbol{\mu \mathbf { g }} / \mathbf{m I})\end{array}$ & $\begin{array}{l}\mathbf{I C}_{\mathbf{5 0}} \\
(\boldsymbol{\mu} \mathbf{M})\end{array}$ \\
\hline Hexane bark extract & $0.050 \pm 0.004$ & $\mathrm{~N} / \mathrm{A}$ \\
Dihydronitidine & $0.0089 \pm 0.0008$ & $0.025 \pm 0.002$ \\
Pellitorine & $1.96 \pm 0.12$ & $8.8 \pm 0.5$ \\
Heitziquinone & $3.55 \pm 0.62$ & $9.7 \pm 1.6$ \\
Sesamin & $>10$ & $>28$ \\
Isobauerenol & $>10$ & $>23$ \\
Caryophyllene oxide & $>10$ & $>49$ \\
Rhoifoline B & $>10$ & $>28$ \\
Isoarnottianamide & $>10$ & $>26$ \\
Nitidine $^{a}$ & $0.038 \pm 0.002$ & $0.099 \pm 0.050$ \\
${\text { WR } 99210^{a}}^{\text {a }}$ & $3.167 \times 10^{-6}$ & $1.2 \times 10^{-5}$ \\
\hline
\end{tabular}

Results \pm SEM from three biological replicates using 3D7 parasites are shown

a Positive control formation in the food vacuole. Haem binding activity requires a positive charge, and with its quaternary nitrogen, nitidine will always be charged. Dihydronitidine, however, will not be charged at the $\mathrm{pH}$ of the food vacuole (pH 4.5-4.9 [29]) due to its low calculated Pkb of 2.8. This suggests that the slow-acting characteristic of dihydronitidine reflects a different mechanism of action between the two compounds. Encouragingly, neither nitidine [26] nor dihydronitidine show chloroquine cross-resistance, with the resistance index $(\mathrm{Dd} 2 / 3 \mathrm{D} 7)$ of $1.7 \pm 0.06$ for dihydronitidine and $1.26 \pm 0.20$ for nitidine being significantly lower than the $10.0 \pm 0.17$ observed for chloroquine.

\section{Effects on mosquito stages of parasite development}

To examine transmission blocking activity, $Z$. heitzii bark hexane extract, dihydronitidine, heitziquinone and pellitorine were tested on mosquito stages of the malaria parasite life cycle for their ability to block ookinete formation in $P$. berghei (ANKA strain). As in blood stages, dihydronitidine showed the greatest activity, although it was far less potent against this stage of the parasite life cycle (Table 2). Heitziquinone had similar levels of activity against both stages but pellitorine did not inhibit ookinete development in vitro. This suggests that both dihydronitidine and heitziquinone target parasite pathways that are active early in the insect stages of the parasite life cycle and have transmission blocking activity.

\section{Traditional use and water extractability of active compounds}

Available ethnobotanical surveys [10] indicate that bark is the only plant part from $Z$. heitzii, locally known as olon in the Republic of Congo, used for treating malaria. The presented results clearly show that the bark is more active compared to leaves and seeds, hence the rationale
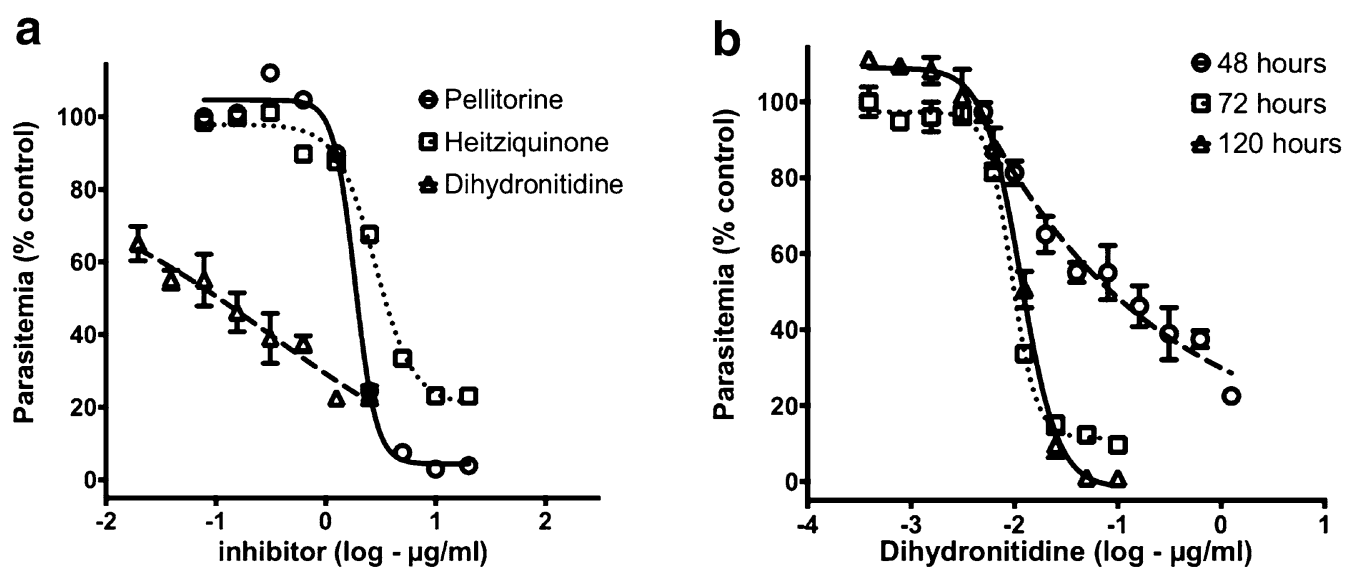

Fig. 3 The slow acting characteristics of dihydronitidine. a Dose-response curves for P. falciparum (3D7) in 48 h in vitro drug assays showing unusual response to dihydronitidine. b Response of parasites to increasing time of dihydronitidine exposure. Maximum efficacy is reached at 72 h, with no improvement with longer exposures 
a

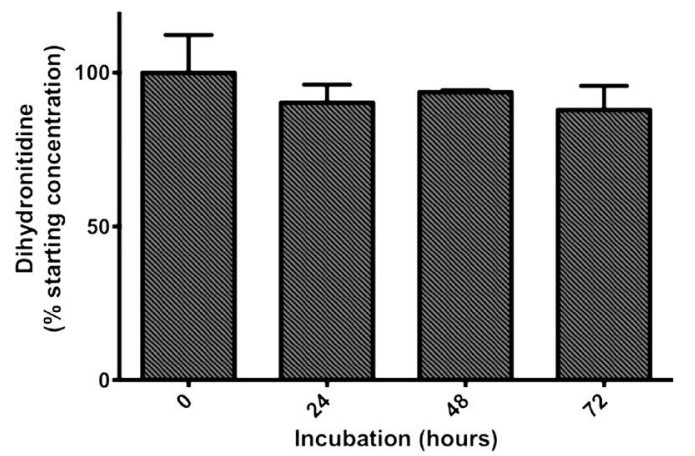

b

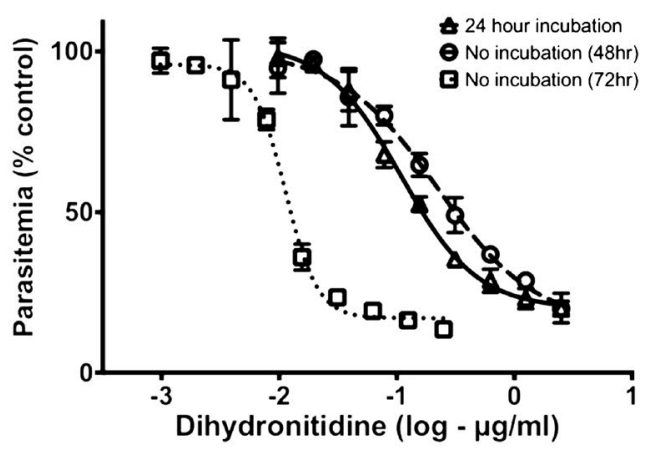

Fig. 4 Dihydronitidine is stable under culture conditions. a Concentration of dihydronitidine after incubation in in vitro culture media at $37^{\circ} \mathrm{C}$ showing minimal breakdown over $72 \mathrm{~h}$. b Incubation of dihydronitidine in culture media for $24 \mathrm{~h}$ does not improve efficacy (mean/SD of three technical replicates)

Table 2 Inhibitory activity of Z. heitzii hexane bark extract, dihydronitidine, heitziquinone and pellitorine against $P$. berghei ANKA ookinete formation

\begin{tabular}{lll}
\hline & $\begin{array}{l}\mathbf{I} \mathbf{C}_{\mathbf{5 0}} \\
(\boldsymbol{\mu g} / \mathbf{m l})\end{array}$ & $\begin{array}{l}\mathbf{I C}_{\mathbf{5 0}} \\
(\boldsymbol{\mu} \mathbf{M})\end{array}$ \\
\hline Hexane bark extract & $1.75 \pm 0.42$ & $\mathrm{~N} / \mathrm{A}$ \\
Dihydronitidine & $0.59 \pm 0.10$ & $1.7 \pm 0.29$ \\
Heitziquinone & $6.20 \pm 1.76$ & $17.0 \pm 4.8$ \\
Pellitorine & $>20$ & $>20$
\end{tabular}

Results are the mean of three biological replicates \pm SEM

behind using the bark as medicine is in accordance with in vitro activity. Dihydronitidine being the main active constituent in $Z$. heitzii is supported by the low anti-parasitic potency of the seed and leaf extracts, which do not contain dihydronitidine (Additional file 3).

Traditional herbal medicines are often prepared as boiled water extracts (decoctions) and this is a common way of preparing extracts of many Zanthoxylum spp. used as anti-malarials [11, 15]. There is, however, little literature available describing preparations of $Z$. heitzii bark for use as an anti-malarial beyond a single report describing the dermal application of bark scrapings [10]. To explore the efficacy of $Z$. heitzii bark extracted as a traditional decoction, the levels of active compounds extracted and the in vitro anti-parasitic activity of the decoction were examined.

The dihydronitidine content in the hexane bark extract was $25.9 \pm 2.4 \%$ (HPLC), corresponding to ca. $0.6 \%$ of the dried bark. The decoction, however, extracted low levels $(\sim 2 \%)$ of the bark content of dihydronitidine; yielding a final concentration in the decoction of $10.7 \pm 0.8 \mu \mathrm{g} / \mathrm{ml}$. Other components that were extracted into boiling water were pellitorine and sesamin
(Additional file 4). Pellitorine showed a relatively low anti-malarial activity, $\left(\mathrm{IC}_{50} 1.96 \mu \mathrm{g} / \mathrm{ml}\right)$, and sesamin was inactive (Table 1). Sesamin, however, has previously been shown to enhance activity of other compounds due to inhibition of CYP3A enzymes involved in compound metabolism [30] and this may increase the anti-malarial potency of dihydronitidine in vivo.

The activity of the lyophilized decoction against $P$. falciparum in vitro was tested. The low dihydronitidine content in a decoction of $Z$. heitzii bark was manifest in the low anti-parasitic activity. When tested against $P$. falciparum (3D7) in vitro, the decoction was only weakly effective, with an $\mathrm{IC}_{50}$ of $9.6 \pm 1.5 \mu \mathrm{g} / \mathrm{ml}$. While far less effective than the purified compounds, this does suggest that the decoction may provide a minimal amount of anti-parasitic activity due to the small amount of dihydronitidine, pellitorine and heitziquinone, and possible synergistic activity among them.

It is not entirely surprising that there is little dihydronitidine in the water decoction of $Z$. heitzii as dihydronitidine is very hydrophobic, with a calculated $\log \mathrm{S}$ (octanol-water partitioning constant) of -4.63 at $\mathrm{pH} 7$ (ACD/Labs). This makes it difficult to extract dihydronitidine using boiling water. Often in traditional medicine, a decoction is acidified using lemon juice. This is may be done to provide a more palatable taste but it also protonates the basic nitrogen often found in many alkaloids, improving their solubility in water. Dihydronitidine, however, has a calculated $\mathrm{pKb}$ of $2.8 \pm 0.9$ (ACD/ Labs), suggesting it would be largely refractory to this treatment. This suggests that the decoction method is not ideal for preparing $Z$. heitzii as an anti-malarial, in contrast to a number of Zanthoxylum spp. containing similar, but water-soluble quaternary benzophenanthridine alkaloids. 


\section{Conclusion}

Zanthoxylum heitzii bark contains three compounds, dihydronitidine, pellitorine, and heitziquinone, with significant activity against $P$. falciparum in in vitro assays. Two of these compounds, dihydronitidine and heitziquinone, also show transmission-blocking activity against $P$. berghei. The most effective compound, dihydronitidine, is active in the low $\mathrm{nM}$ range and may be considered a lead molecule for drug development. The relatively poor extractability of dihydronitidine limits its concentrations in water preparations of $Z$. heitzii, suggesting that using preparations with non-polar extraction methods involving oil or fat, or simply using the powdered bark, could improve the anti-malarial characteristics of this traditional medicine.

\section{Additional files}

Additional file 1. ${ }^{1}$ H NMR spectrum of dihydronitidine isolated from $Z$.
heitzii.

Additional file 2. Screening of fractions of Z. heitzii bark extract.

Additional file 3. HPLC chromatogram of Z. heitzii bark, leaf and seed hexane extracts.

Additional file 4. HPLC chromatogram of Z. heitzii water extract.

\section{Authors' contributions}

CDG has designed and carried out the parasite assays, analyzed and interpreted the data and, together with IA, drafted and revised the paper. IA also carried out the analysis and contributed to the study design and interpretation of data. VM carried out the ookinete assays. BM collected and identified the plant material. KEM and HW have contributed to the conception and design, extraction, isolation and identification of the isolated compounds and revising the article critically. GM contributed to experimental design and revision of the manuscript. All authors read the final version of the manuscript.

\section{Author details}

${ }^{1}$ School of BioSciences, University of Melbourne, Parkville, VIC 3010, Australia. 2 Department of Pharmaceutical Chemistry, School of Pharmacy, University of Oslo, P. O. Box 1068, Blindern, 0316 Oslo, Norway. ${ }^{3}$ National Polytechnic High School, Marien Ngouabi University, BP 69 Brazzaville, Republic of Congo.

\section{Acknowledgements}

We thank the Australian Red Cross for blood. We also acknowledge Ove Alexander Høgmoen Åstrand commenting on impurities present in the isolated dihydronitidine and Nastaran Moussavi for involvement in purifying compounds.

\section{Competing interests}

The authors declare that they have no competing interests.

\section{Availability of data and materials}

Data on the chemical work (isolation, characterization, analysis and identification of the compounds) are located in the Department of Pharmaceutical Chemistry, School of Pharmacy, University of Oslo, and data on the antiparasitic work in the School of Biosciences, University of Melbourne (https:// figshare.com under doi 10.4225/49/57DA63BF24867). Samples of the Z. heitzii bark can be obtained from the Department of Pharmaceutical Chemistry, School of Pharmacy, University of Oslo.

\section{Consent for publication}

Not applicable.
Ethics approval and consent to participate Not applicable.

\section{Funding}

This research has been funded by a Program Grant from the National Health and Medical Research Council of Australia and a Discovery Project from the Australian Research Council.

Received: 8 July 2016 Accepted: 9 September 2016 Published online: 20 September 2016

\section{References}

1. WHO. World malaria Report 2013. Geneva, World Health Organization, 2013. [http://www.who.int/malaria/publications/world_malaria_ report_2013/en/], Accessed 21 June 2016.

2. World Bank Group. The World Bank—Data [http://data.worldbank.org/], Accessed 21 June 2016.

3. WHO. Counterfeit antimalarial medicines: detection tool. WHO Drug Information. Geneva, World Health Organization, 2013;27.

4. Tabernero P, Fernandez FM, Green M, Guerin PJ, Newton PN. Mind the gaps - the epidemiology of poor-quality anti-malarials in the malarious world - analysis of the worldwide antimalarial resistance network database. Malar J. 2014;13:139.

5. Willcox M, Bodeker G. Frequency of use of traditional herbal medicines for the treatment and prevention of malaria: An overview of the literature. In: Willcox M, Bodeker G, Rasoanaivo P, Addae-Kyereme J, editors. Traditional medicinal plants and malaria. Boca Raton: CRC Press; 2004

6. Onguene PA, Ntie-Kang F, Lifongo LL, Ndom JC, Sippl W, Mbaze LM. The potential of anti-malarial compounds derived from African medicinal plants. Part I: a pharmacological evaluation of alkaloids and terpenoids. Malar J. 2013;12:449.

7. Ashley EA, Dhorda M, Fairhurst RM, Amaratunga C, Lim P, Suon S, et al. Spread of artemisinin resistance in Plasmodium falciparum malaria. N Engl J Med. 2014;371:411-23.

8. Kirira PG, Rukunga GM, Wanyonyi AW, Muregi FM, Gathirwa JW, Muthaura CN, et al. Anti-plasmodial activity and toxicity of extracts of plants used in traditional malaria therapy in Meru and Kilifi districts of Kenya. J Ethnopharmacol. 2006;106:403-7.

9. Randrianarivelojosia M, Rasidimanana VT, Rabarison H, Cheplogoi PK, Ratsimbason M, Mulholland DA, et al. Plants traditionally prescribed to treat tazo (malaria) in the eastern region of Madagascar. Malar J. 2003;2:25.

10. PROTA: Zanthoxylum heitzii (Aubrév. \& Pellegr.) P.G.Waterman [http://uses. plantnet-project.org/en/Zanthoxylum_heitzii_(PROTA)], Accessed 21 June 2016.

11. Patiño LOJ, Prieto RJA, Cuca SLE. Zanthoxylum genus as potential source of bioactive compounds. In: Rasooli I, editor. Bioactive compounds in phytomedicine. Rijeka: InTech; 2012. p. 185-218.

12. Saslis-Lagoudakis CH, Savolainen V, Williamson EM, Forest F, Wagstaff SJ, Baral SR, et al. Phylogenies reveal predictive power of traditional medicine in bioprospecting. Proc Natl Acad Sci USA. 2012;109:15835-40.

13. Gakunju DMN, Mberu EK, Dossaji SF, Gray Al, Waigh RD, Waterman PG, et al. Potent antimalarial activity of the alkaloid nitidine, isolated from a Kenyan herbal remedy. Antimicrob Agents Chemother. 1995;39:2606-9.

14. Adesina SK. The Nigerian Zanthoxylum; chemical and biological values. Afr J Trad CAM. 2005:2:282-301.

15. Lye K, Bukenya-Ziraba R, Tabuti J, Waako P. Plant-medicinal dictionary for East Africa. Kampala: Department of Botany, Makerere University; 2008.

16. Mikolo B, Matos L, Massamba D, Mamonekene V, Miller T. Extracts from the bark of Fagara heitzii (Aubr. et Pel.) (Rutaceae) tree are toxic to two weevils and the American cockroach. Entomol Res. 2009;39:401-5.

17. Overgaard HJ, Sirisopa P, Mikolo B, Malterud KE, Wangensteen H, Zou YF, et al. Insecticidal activities of bark, leaf and seed extracts of Zanthoxylum heitzii against the African malaria vector Anopheles gambiae. Molecules. 2014:19:21276-90.

18. Moussavi N, Malterud K, Mikolo B, Dawes D, Chandre F, Corbel V, Massamba D, et al. Identification of chemical constituents of Zanthoxylum heitzii stem bark and their insecticidal activity against the malaria mosquito Anopheles gambiae. Parasit Vectors. 2015;8:503. 
19. Wangensteen H, Ho GT, Tadesse M, Miles CO, Moussavi N, Mikolo B, Malterud KE. A new benzophenanthridine alkaloid and other bioactive constituents from the stem bark of Zanthoxylum heitzii. Fitoterapia. 2016;109:196-200.

20. Trager W, Jensen JB. Human malaria parasites in continuous culture. Science. 1976;193:673-5.

21. Smilkstein M, Sriwilaijaroen N, Kelly JX, Wilairat P, Riscoe M. Simple and inexpensive fluorescence-based technique for high-throughput antimalarial drug screening. Antimicrob Agents Chemother. 2004;48:1803-6.

22. Goodman CD, Su V, McFadden GI. The effects of anti-bacterials on the malaria parasite Plasmodium falciparum. Mol Biochem Parasit. 2007;152:181-91.

23. Delves MJ, Ramakrishnan C, Blagborough AM, Leroy D, Wells TNC, Sinden RE. A high-throughput assay for the identification of malarial transmission-blocking drugs and vaccines. Int J Parasitol. 2012;42:999-1006.

24. Noel ZG, Yao DJ, Philippe G. Phytochemical and pharmacological studies of alcoholic extract of Fagara macrophylla (Oliv) Engl (Rutaceae): chemical structure of active compound inducing antipaludic activity. J Chin Clin Med. 2007;2:205-10.
25. Althaus JB, Kaiser M, Brun R, Schmidt TJ. Antiprotozoal activity of Achillea ptarmica (Asteraceae) and its main alkamide constituents. Molecules. 2014; 19:6428-38.

26. Nyangulu JM, Hargreaves SL, Sharples SL, Mackay SP, Waigh RD, Duval $\mathrm{O}$, et al. Antimalarial benzo[c] phenanthridines. Bioorg Med Chem Lett. 2005;15:2007-10

27. Bouquet J, Rivaud M, Chevalley S, Deharo E, Jullian V, Valentin A. Biological activities of nitidine, a potential antimalarial lead compound. Malar J. 2012;11:67.

28. Jullian V, Bourdy G, Georges S, Maurel S, Sauvain M. Validation of use of a traditional antimalarial remedy from French Guiana, Zanthoxylum rhoifolium Lam. J Ethnopharmacol. 2006;106:348-52.

29. Hayward R, Saliba KJ, Kirk K. The pH of the digestive vacuole of Plasmodium falciparum is not associated with chloroquine resistance. J Cell Sci. 2006;119:1016-25.

30. Parker RS, Sontag TJ, Swanson JE. Cytochrome P4503A-dependent metabolism of tocopherols and inhibition by sesamin. Biochem Biophys Res Commun. 2000;277:531-4.

\section{Submit your next manuscript to BioMed Central and we will help you at every step:}

- We accept pre-submission inquiries

- Our selector tool helps you to find the most relevant journal

- We provide round the clock customer support

- Convenient online submission

- Thorough peer review

- Inclusion in PubMed and all major indexing services

- Maximum visibility for your research

Submit your manuscript at www.biomedcentral.com/submit 